Health and Safety Research Division

\title{
COMPARATIVE STUDY OF COMBUSTION PRODUCT EMISSIONS OF PAKISTANI COAL BRIQUETTES AND TRADITIONAL PAKISTANI DOMESTIC FUELS
}

E. A. Wachter, R. B. Gamrnage, J. W. Haas, III, and D. L. Wilson Measurement Systems Research Group Health and Safety Research Division Oak Ridge National Laboratory

J. C. DePriest and J. Wade Midwest Technical Institute

N. Ahmad, F. Sibtain, and M. Zahid Raza

Fuel Research Centre

Pakistan Council of Scientific and Industrial Research

Date Completed: March 1992

Date Published: October 1992

NOTICE: This document contains information of a preliminary nature. It is subject to revisions or corrections and therefore does not represent a final report.

Prepared by the

OAK RIDGE NATIONAL LABORATORY

Oak Ridge, Tennessee 37831

managed by

MARTIN MARIETTA ENERGY SYSTEMS, INC

for the

U.S. DEPARTMENT OF ENERGY under contract DE-AC05-84OR21400

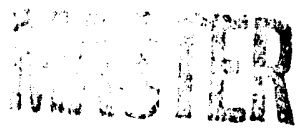


TABLE OF CONTENTS

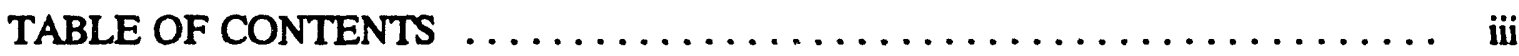

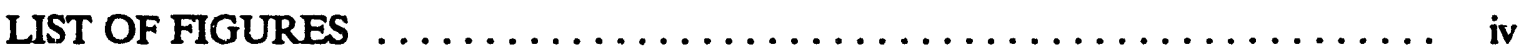

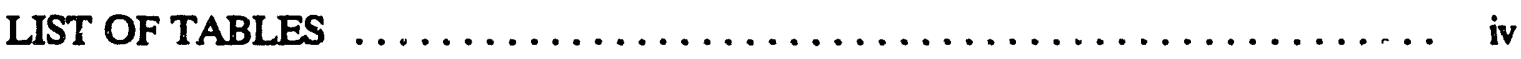

ACKNOWLEDGEMENTS. $\ldots \ldots \ldots \ldots \ldots \ldots \ldots \ldots \ldots \ldots \ldots, \quad \mathbf{v}$

ABSTRACT $\ldots \ldots \ldots \ldots \ldots \ldots \ldots \ldots \ldots \ldots \ldots \ldots \ldots \ldots \ldots \ldots \ldots \ldots \ldots \ldots \ldots$

1. INTRODUCTION $\ldots \ldots \ldots \ldots \ldots \ldots \ldots \ldots \ldots \ldots \ldots \ldots \ldots \ldots \ldots \ldots, 2$

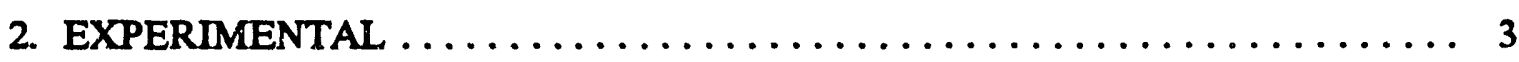

2.1 COMBUSTION FACILITIES $\ldots \ldots \ldots \ldots \ldots \ldots \ldots \ldots \ldots \ldots \ldots, 3$

2.2 COMBUSTION PROTOCOL $\ldots \ldots \ldots \ldots \ldots \ldots \ldots \ldots \ldots \ldots \ldots, 3$

2.3 INSTRUMENTATION $\ldots \ldots \ldots \ldots \ldots \ldots \ldots \ldots \ldots \ldots \ldots \ldots \ldots \ldots \ldots$

2.4 MONITORING PERIOD $\ldots \ldots \ldots \ldots \ldots \ldots \ldots \ldots \ldots \ldots \ldots \ldots, 6$

2.5 SAMPLES TESTED $\ldots \ldots \ldots \ldots \ldots \ldots \ldots \ldots \ldots \ldots \ldots \ldots, 6 \ldots \ldots$

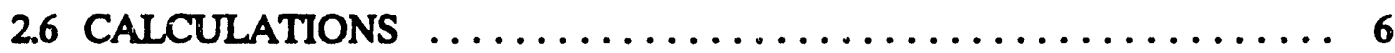

2.7 QUALITY ASSURANCE $\ldots \ldots \ldots \ldots \ldots \ldots \ldots \ldots \ldots \ldots \ldots \ldots \ldots \ldots$

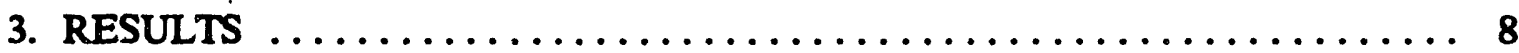

3.1 COMBUSTION EFFICIENCY $\ldots \ldots \ldots \ldots \ldots \ldots \ldots \ldots \ldots \ldots, 8$

3.2 RESPIRABLE PARTICULATES $\ldots \ldots \ldots \ldots \ldots \ldots \ldots \ldots \ldots \ldots, 9$

3.3 ORGANIC VOLATILES $\ldots \ldots \ldots \ldots \ldots \ldots \ldots \ldots \ldots \ldots \ldots \ldots \ldots \ldots \ldots, 12$

3.4 ORGANIC VOLATILES AND SEMIVOLATILES $\ldots \ldots \ldots \ldots \ldots \ldots, 14$

3.5 CARBON MONOXIDE $\ldots \ldots \ldots \ldots \ldots \ldots \ldots \ldots \ldots \ldots \ldots \ldots, 16$

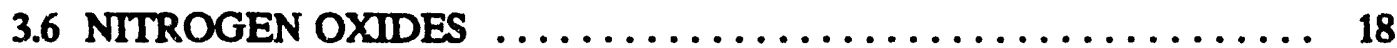

3.7 SULFUR DIOXIDE $\ldots \ldots \ldots \ldots \ldots \ldots \ldots \ldots \ldots \ldots \ldots \ldots \ldots \ldots, 18$

3.8 COMPARISON OF OXIDE RESULTS $\ldots \ldots \ldots \ldots \ldots \ldots \ldots \ldots, 18$

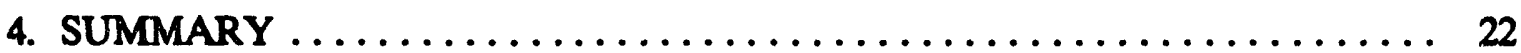

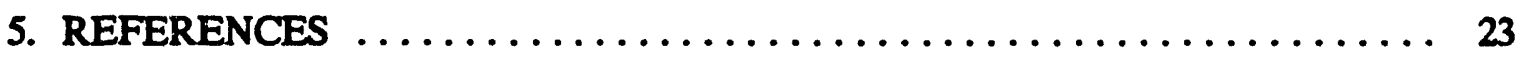




\section{LIST OF FIGURES}

Figure 1. Briquette combustion shed at ORNL $\ldots \ldots \ldots \ldots \ldots \ldots \ldots$

Figure 2. Analysis of inorganic and organic respirable particulates $\ldots \ldots \ldots \ldots$

Figure 3. GC/PID analysis of VOC combustion products $\ldots \ldots \ldots \ldots \ldots$

Figure 4. GC/MS analysis of VOC and SVOC combustion products ...... 15

Figure 5. Carbon monoxide emissions $\ldots \ldots \ldots \ldots \ldots \ldots \ldots \ldots \ldots \ldots$

Figure 6. Nitrogen oxides emissions $\ldots \ldots \ldots \ldots \ldots \ldots \ldots \ldots \ldots \ldots$

Figure 7. Sulfur dioxide emissions $\ldots \ldots \ldots \ldots \ldots \ldots \ldots \ldots \ldots \ldots \ldots$

Figure 8. Comparision of oxide emissions $\ldots \ldots \ldots \ldots \ldots \ldots \ldots \ldots \ldots$

\section{LIST OF TABLES}

Table 1. Composition of coal briquettes $\ldots \ldots \ldots \ldots \ldots \ldots \ldots \ldots \ldots$

Table 2. Gas standards for instrument calibration $\ldots \ldots \ldots \ldots \ldots \ldots \ldots$

Table 3. Combustion data for samples tested. $\ldots \ldots \ldots \ldots \ldots \ldots \ldots$

Table 4. Total respirable particulate emissions $\ldots \ldots \ldots \ldots \ldots \ldots \ldots$

Table 5. Canadian domestic indoor air quality guidelines $\ldots \ldots \ldots \ldots \ldots \ldots$

Table 6. Analyses of inorganic particulates $\ldots \ldots \ldots \ldots \ldots \ldots \ldots \ldots \ldots$

Table 7. Analyses of organic particulates $\ldots \ldots \ldots \ldots \ldots \ldots \ldots \ldots \ldots$

Table 8. Effluent an $\quad$ lysis by photoionization GC $\ldots \ldots \ldots \ldots \ldots \ldots \ldots$

Table 9. Relative GC-MS response, by tentative chemical class . . . . . . 16

Table 10. Peak concentrations, peak times, and relative emission factors for inorganic oxides $\ldots \ldots \ldots \ldots \ldots \ldots \ldots \ldots \ldots \ldots \ldots \ldots \ldots$ 


\section{ACKNOWLEDGEMENTS}

This work was supported by the Pakistan Mission of the United States Agency for International Development (US-AID), under an interagency agreement between US-AID and the United States Department of Energy (US-DOE).

The authors wish to express their appreciation to E. L. Fuller, C. E. Higgins, C. Y. Ma, and J. H. Moneyhun of ORNL for their assistance in the analysis of numerous samples. 


\title{
COMPARATIVE STUDY OF COMBUSTION PRODUCT EMISSIONS OF \\ PAKISTANI COAL BRIQUETTES AND \\ TRADITIONAL PAKISTANI DOMESTIC FUELS
}

\author{
E. A. Wachter, R. B. Gammage, J. W. Haas, III, D. L. Wilson, J. C. DePriest, ${ }^{1}$ J. Wade, \\ N. Ahmad, ${ }^{2}$ F. Sibtain, ${ }^{2}$ and M. Zahid Raza ${ }^{2}$
}

\begin{abstract}
A comparative emissions study was conducted on combustion products of various solid domestic cooking fuels; the objective was to compare relative levels of organic and inorganic toxic emissions from traditional Pakistani fuels (wood, wood charcoal, and dried animal dung) with manufactured low-rank coal briquettes (Lakhra and Sor-Range coals) under conditions simulating domestic cooking. A small combustion shed $\left(12 \mathrm{~m}^{3}\right.$ internal volume, air exchange rate $14 \mathrm{~h}^{-1}$ ) was used to simulate south Asian cooking rooms. 200-g charges of the various fuels were ignited in an Angethi stove located inside the shed, then combusted to completion; effluents from this combustion were monitored as a function of time. Measurements were made of respirable particulates, volatile and semi-volatile organics, $\mathrm{CO}, \mathrm{SO}_{2}$ and $\mathrm{NO}_{x}$
\end{abstract}

Overall it appears that emissions from coal briquettes containing combustion amendments (slaked lime, clay, and potassium nitrate oxidizer) are no greater than emissions from traditional fuels, and in some cases are significantly lower; generally, emissions are highest for all fuels in the early stages of combustion. Coal amendment proved effective in reducing respirable particulate emissions by a factor of about a-fold compared to unamended coal; relative to traditional fuels, emission levels for the amended coals were comparable or lower. No significant emissions of toxic metals were detected. Of all the fuels investigated, the amended Lakhra coal produced the lowest volatile and semivolatile organics emissions, while unamended Lakhra coal produced the highest organics emissions; organics emissions from amended coals were comparable with those from traditional fuels. Peak concentrations of $\mathrm{CO}$ in the range of $100-300 \mathrm{ppm}$ were measured for all fuels; amended coals produced somewhat lower integrated emissions of $\mathrm{CO}$ than unamended coal, but all were comparable to traditional fuels. Coal additives significantly reduced total production of $\mathrm{SO}_{2}$ (about 3- to 4-fold relative to unamended coal), but were ineffective in reducing peak emission of $\mathrm{SO}_{2}$, which occurred during the ignition phase. Total $\mathrm{SO}_{2}$ emissions from amended coals were comparable to those of traditional fuels. $\mathrm{NO}_{\mathrm{z}}$ emissions were comparable for all fuels for both peak and integrated emission.

\footnotetext{
${ }^{1}$ Midwest Technical Institute

${ }^{2}$ Fuel Research Centre, Pakistan Council of Scientific and Industrial Research
} 


\section{INTRODUCTION}

The Fuel Research Centre of the Pakistan Council of Scientific and Industrial Research (FRC-PCSIR) has developed several low-smoking coal briquette products using an inexpensive, dry briquetting process. If means can be found for using Pakistan's high-sulfur, lignitic coal economically and safely, it can be substituted for the traditional cooking fuels: wood, charcoal, animal dung, and kerosene. Deforestation could thus be slowed and kerosene imports reduced. Market evaluations of coal-based briquettes have indicated their attractiveness for use in domestic cooking, firing brick kilns, heating chicken brooders at poultry farms, and for cooking at road-side restaurants. The economics of the briquette products are favorable, with the relative ratio of BTU per Pakistani Rupee being [briquettes] $>$ [wood] $>$ [charcoal] $>$ [kerosene]

The United States Agency for International Development (USAID) has provided machinery and equipment to carry out development of coal briquetting. Composition of the coal briquette products developed are summarized in Table 1. No evaluation had previously been conducted of combustion product emissions from these coal briquettes, or their potential impacts on indoor air quality and human health.

\begin{tabular}{|c|c|c|}
\hline Briquette & Component & Composition \\
\hline Coal A & Lakhra Coal & $64.5 \%$ \\
\hline & Slaked Lime & $24.5 \%$ \\
\hline & Clay & $10.0 \%$ \\
\hline & Potassium Nitrate & $1.0 \%$ \\
\hline Coal B & Lakhra Coal & $54.8 \%$ \\
\hline & Slaked Lime & $20.8 \%$ \\
\hline & Clay & $8.5 \%$ \\
\hline & Potassium Nitrate & $0.8 \%$ \\
\hline & Coke Dust & $15.0 \%$ \\
\hline Coal C & Sor-Range Coal & $83.3 \%$ \\
\hline & Slaked Lime & $5.7 \%$ \\
\hline & Clay & $10.0 \%$ \\
\hline & Potassium Nitrate & $1.0 \%$ \\
\hline Coal D & Lakhra Coal & $100 \%$ \\
\hline
\end{tabular}

Table 1. Composition of coal briquettes. Specific surface of slaked lime, $7.67 \mathrm{~m}^{2} / \mathrm{g}$, measured by nitrogen sorption, courtesy E.L. Fuller, ORNL. 


\section{EXPERIMENTAL}

\subsection{COMBUSTION FACILITIES}

A small outdoor combustion facility was constructed on the Oak Ridge Reservation; this building consisted of a commercial aluminum storage shed (4-m wide $\times 3-\mathrm{m}$ deep $\times 2-\mathrm{m}$ high, internal volume $12 \mathrm{~m}^{3}$ ), with a non-combustible aluminum floor; a tarpaulin was affixed $0.5 \mathrm{~m}$ above the roof of the shed to minimize heat gain from sunshine. A schematic of the test facility is shown in Figure 1. A variable-speed fan connected to an external air intake allowed fresh air to be admitted into the building at a continuous rate; for all tests reporte/ $\perp$ here, the fan was set to provide an air exchange rate of $14 \mathrm{~h}^{-1}$. Air samples were collected during combustion using one of two approaches: particulates, volatile organics (VOCs) and semi-volatile organics (SVOCs) were collected on integrative filters situated inside the shed, approximately $0.3 \mathrm{~m}$ above and to the side of the burning sample; VOCs and inorganic oxides were sampled and analyzed continuously via ports on a wide-bore recirculating sample manifold, which had a fan directed into the mouth of the manifold. Two additional fans were located at opposite corners of the shed to facilitate homogenization of the interior air volume.

\section{COMBUSTION PROTOCOL}

Fuels were combusted on the grill of an Angethi stove, which is the traditional domestic cooking stove in Pakistan. The Angethi stove consists of a cylindrical metal barrel placed on end, with a metal grill situated radially at the mid-point. The upper portion includes a baked mud liner, which reduces the internal diameter from approximately $30 \mathrm{~cm}$ to $25 \mathrm{~cm}$; the combustion chamber is approximately $12-\mathrm{cm}$ deep. Fuel was placed in the upper chamber on top of the grill, and in our experiments was burned uncovered. The stove utilized in this study was designed to accept approximately $1-$ to $1.5-\mathrm{kg}$ charcoal. Because of the copious emissions from this amount of fuel, the amount of fuel used was reduced to $200 \mathrm{~g}$ for these studies in order to maintain gas concentrations within the span of our monitoring instruments. 


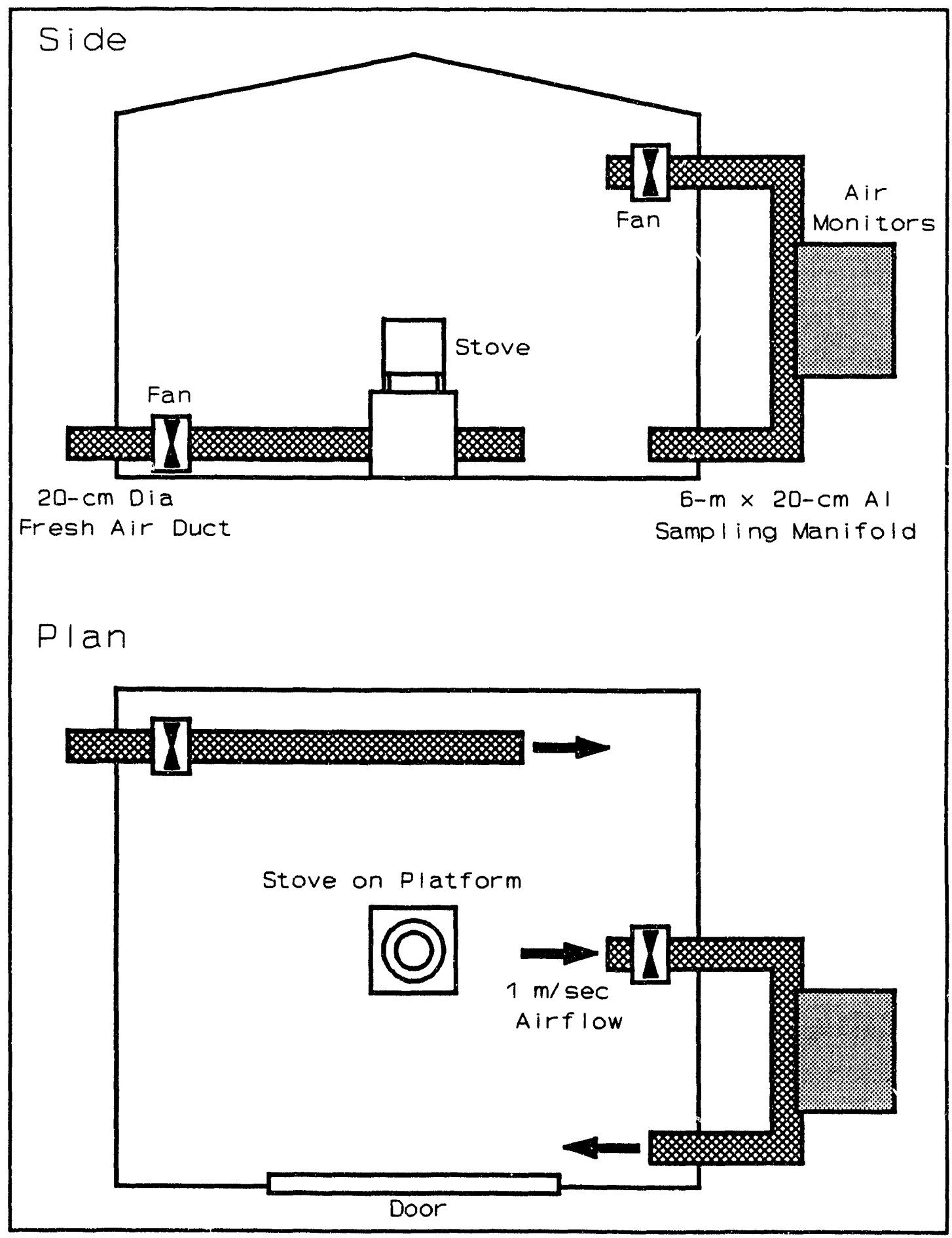

Figure 1. Briquette combustion shed at ORNL. 
The $2.5 \mathrm{~cm} \times 7.5 \mathrm{~cm}$ briquettes were broken into smaller pieces (ca. 1 - to $2-\mathrm{cm}$ on edge) to facilitate combustion of the smaller than normal charge. The fuel was arranged in a pyramidal pile in the center of the grill, and the loaded stove was placed at the center of the floor of the shed. Fuel was ignited using a propane torch, held below the grate for approximately 5 minutes; emission monitoring commenced upon contact of the flame with the fuel. After this ignition step, the door to the shed was kept closed throughout the remainder of emission testing to maintain the standard air exchange rate. In blank tests using only the propane torch and no solid fuel, no significant emissions of the target pollutants were detected. An oxygen monitor was used inside the shed to verify that oxygen depletion did not occur during combustion.

\section{INSTRUMENTATION}

A battery of instruments was required to conduct the full set of emissions measurements. These are classified below by analyte:

Inorganic particulates: Harvard particulate sampler, $0.0035 \mathrm{~m}^{3} \mathrm{~min}^{-1}$ flow rate, $2-\mu \mathrm{m}$ pore, 41-mm diameter PTFE membrane filter, 200-min sampling interval. Samples analyzed gravimetrically and by ICP/MS, EPA Method 200.8.

Organic particulates: $\quad$ Pallflex particulate sampler, $0.010 \mathrm{~m}^{3} \mathrm{~min}^{-1}$ flow rate, Putnam Type T60A20 glass fiber membrane filter, 200-min sampling interval. Samples analyzed gravimetrically and for polynuclear aromatic content by ORNL method ACD-8270, based on EPA Method 625.

VOCs/SVOCs:

Triple sorbent trap, composed of 14-mm long x 4-mm diameter beds of Supelco Carbotrap C, Carbotrap, and Carbosieve S-III, in series; $0.170 \mathrm{~m}^{3} \mathrm{~min}^{-1}$ flow rate, 15 -min sampling interval. Collected samples analyzed by $250^{\circ} \mathrm{C}$ thermally-aided purge and cryogenic trap GC/MS, $70 \mathrm{eV}$ electron-impact ionization. 
VOCs:

Photovac $10 S 50$ photoionization gas chromatograph (GC/PID), ambient temperature operation; Photovac SA1020 column, 530 $\mu \mathrm{m}$ diameter wide-bore fused silica, Chrompack CPSil 5 CB coating. Grab sampling analyzed by immediate on-column injection.

Carbon Monoxide:

GasTech GX-4000 electrochemical monitor, 0-250 ppm range.

Sulfur Dioxide:

GasTech GX-4000 electrochemical monitor, 0-50 ppm range.

Nitrogen Oxides:

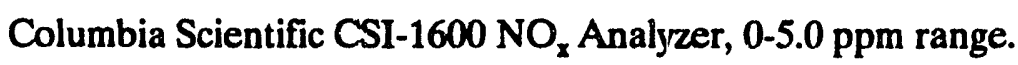

Oxygen Monitor:

GasTech GX-4000 electrochemical monitor, 0-25\% range.

\section{MONITORING PERIOD}

Complete combustion was generally achieved within about one hour; however, to provide accuzate emission factors, monitoring was continued until the gas analyzers returned to baseline; this generally required monitoring for a period of 3-4 hours following ignition.

\section{SAMPLES TESTED}

All samples studied were provided by the FRC, and representec either traditional Pakistani domestic fuels or potential fuel replacements. Along with the four coal briquette types shown in Table 1, samples of wood, wood charcoal, and animal dung were tested. Order of burning of the various samples was randomized. A minimum of three combustion runs were conducted for each fuel.

\section{CALCULATIONS}

Combustion data reported are averaged for replicate analyses. Since combustion conditions (such as air exchange rate and sample size) were maintained within a carefully 
regulated range, this approach minimizes the effects of differences between individual burns; such differences might arise due to minor variations in initiation and rate of combustion, incomplete combustion in briquette cores, loss of material through the grate of the Angethi stove, and sample inhomogeneities. Based on the approach used by Wilson and Hawthorne in earlier briquette combustion tests, the following calculations were made [1]:

\author{
Combustion Efficiency: $\quad[1-\mathrm{A} / \mathrm{W}] \bullet 100 \%$ \\ Respirable Particulates: $\quad\left[\delta \mathrm{W}_{\mathrm{f}} \bullet \mathrm{V}\right] /[\mathrm{W} \cdot \mathrm{F} \bullet \mathrm{T}]$ \\ Relative Emission Factor: $\quad$ / C/W
}

where $A$ is the ash weight $(\mathrm{kg}), \mathrm{W}$ is the weight of fuel $(\mathrm{kg}), \delta \mathrm{W}_{\mathrm{f}}$ is the weight of particulates on a filter (mg), V is the chamber volume $\left(\mathrm{m}^{3}\right), F$ is the sampling rate of sampler $\left(\mathrm{m}^{3} / \mathrm{min}\right)$, $T$ is the sampling interval ( $\mathrm{min})$, and $\int \mathrm{C}$ is the integrated concentration of a pollutant $\left(\mathrm{g} / \mathrm{m}^{3}\right)$.

\title{
27 QUALITY ASSURANCE
}

Gas monitors were calibrated throughout the study utilizing commercially available standards, as shown in Table 2. The GC/PID system was calibrated prior to each combustion run using toluene and benzene vapor standards. Integrating samplers (particulates and VOC/SVOC traps) were calibrateci according to the appropriate EPA protocol (identified in Section 2.3).

\begin{tabular}{|c|c|c|}
\hline Calibrant & Concentration & Source \\
\hline Air & Ultra Zero Grade & Alphagaz \\
\hline $\mathrm{CO}$ & $47 \mathrm{ppm}$ & Alphagaz \\
\hline $\mathrm{SO}_{2}$ & $1.3 \mathrm{ppm}$ & Alphagaz \\
\hline $\mathrm{NO}_{2}$ & $5 \mathrm{ppm}$ & Alphagaz \\
\hline Benzene & $9.7 \mathrm{ppm}$ & Scott Specialty Gases \\
\hline Toluene & $9.9 \mathrm{ppm}$ & Scott Specialty Gases \\
\hline
\end{tabular}

Table 2. Gas standards for instrument calibration. 


\section{RESULTS}

\subsection{COMBUSTION EFFICIENCY}

Combustion efficiency is the percent weight loss of combusted fuel, primarily via combustion of carbonaceous components, and is based on gravimetric analysis of ash. Combustion efficiencies for the fuel samples varied substantially, with traditional fuels providing the most complete combustion. Average values and sample ranges are shown in Table 3. Traditional fuels burned readily, leaving little residue; because of the very fine, flocculent nature of the ash from animal dung, complete collection of ash was impossible, requiring estimation of combustion efficiency. Among the briquettes, Coal D, which is composed of pure, unamended Lakhra coal, furnished the most complete combustion. Because of its non-combustible amendments, Coal C burned less completely than Coal D, and produced a somewhat coarser ash. Coals A and B burned significantly less efficiently, and produced hard cinder-like ash. Furthermore, these very hard briquettes frequently left an unburned crire, which complicates calculation of combustion efficiencies.

\begin{tabular}{|c|c|c|c|c|}
\hline \multirow{2}{*}{ Sample } & \multicolumn{3}{|c|}{ Combustion Efficiency (CE) } & Ash Description \\
\cline { 2 - 6 } & Average & Range & $N$ & \\
\hline Coal A & $54.4 \pm 5.1$ & $61.3-49.0$ & 3 & Cinders \\
\hline Coal B & $40.8 \pm 8.5$ & $52.2-32.0$ & 3 & Cinders \\
\hline Coal C & $77.0 \pm 3.9$ & $81.6-71.1$ & 4 & Grainy \\
\hline Coal D & $80.5 \pm 3.2$ & $83.7-77.3$ & 3 & Grainy \\
\hline Wood & 92.6 & - & 1 & Fine-Grainy \\
\hline Charcoal & $96.1 \pm 0.4$ & $95.7-96.5$ & 2 & Grainy \\
\hline Dung & $>95$ & - & 3 & Fine \\
\hline
\end{tabular}

Table 3. Combustion data for samples tested. 


\section{RESPIRABLE PARTICULATES}

Respirable inorganic and organic particulate emissions from each fuel type are summarized in Table 4. Inorganic particulates were collected using Harvard samplers at three locations: Proximal, at a lateral distance of $25 \mathrm{~cm}$ from the Angethi stove; Medial, at a distance of $50 \mathrm{~cm}$; and Distal, $100 \mathrm{~cm}$; sampler inlets were at an elevation $25 \mathrm{~cm}$ above the top of the stove, approximating the face location of a cook at the stove. As expected, despite thorough mixing of the air in the shed, particulate levels were found to fall rapicily with distasce from the source. Amended coal briquettes (Coals A, B, and C) produced inorganic particulates at levels comparable to wood; animal dung and charcoal emissions were approximately 3-fold greater; and Coal D produced the highest emissions, with levels roughly 4-fold greater than the amended coals. Organic particulates, collected on a single Pallflex sampler located $25 \mathrm{~cm}$ lateral and vertical distance from the stove, showed the same trend in total emissions. The gravimetric data is compared graphically in Figure 2. These emission profiles support the conclusion that particulate emissions fall into two categorics: a low emission category, consisting of Coals A, B, and C, along with wood; and a high emission category, Coal D, dung, and charcoal. In comparison with Canadian domestic indoor air quality standards as provided in Table 5 [2], the relative levels are not exceptionally high: for example, a $200-\mathrm{g}$ sample of Coal D produces a maximum estimated 1-h particulate exposure of $1-2 \mu \mathrm{g} / \mathrm{m}^{3}$ under the combustion conditions utilized in this study; this is considerably lower than the 1-hr standard of $100 \mu \mathrm{g} / \mathrm{m}^{3}$.

\begin{tabular}{|c|c|c|c|c|}
\hline Sample & \multicolumn{3}{|c|}{ Inorganic } & Organic \\
\cline { 2 - 6 } & Proximal & Modial & Distal & \\
\hline Coal A & $0.292 \pm 0.120$ & $0.172 \pm 0.120$ & $0.095 \pm 0.120$ & 0.186 \\
\hline Coal B & $0.249 \pm 0.034$ & $0.198 \pm 0.059$ & $0.138 \pm 0.034$ & - \\
\hline Coal C & $0.232 \pm 0.138$ & $0.120 \pm 0.103$ & $0.095 \pm 0.112$ & 0.345 \\
\hline Coal D & $0.855 \pm 0.421$ & $0.731 \pm 0.353$ & $0.731 \pm 0.327$ & 0.720 \\
\hline Wood & 0.258 & 0.215 & 0.198 & 0.147 \\
\hline Charcoal & $0.783 \pm 0.447$ & $0.585 \pm 0.387$ & $0.559 \pm 0.387$ & - \\
\hline Dung & $0.774 \pm 0.413$ & $0.344 \pm 0.069$ & $0.430 \pm 0.146$ & 0.564 \\
\hline
\end{tabular}

Table 4. Total respirable particulate emissions, $\mathrm{mg} / \mathrm{kg}$ fuel combusted. 


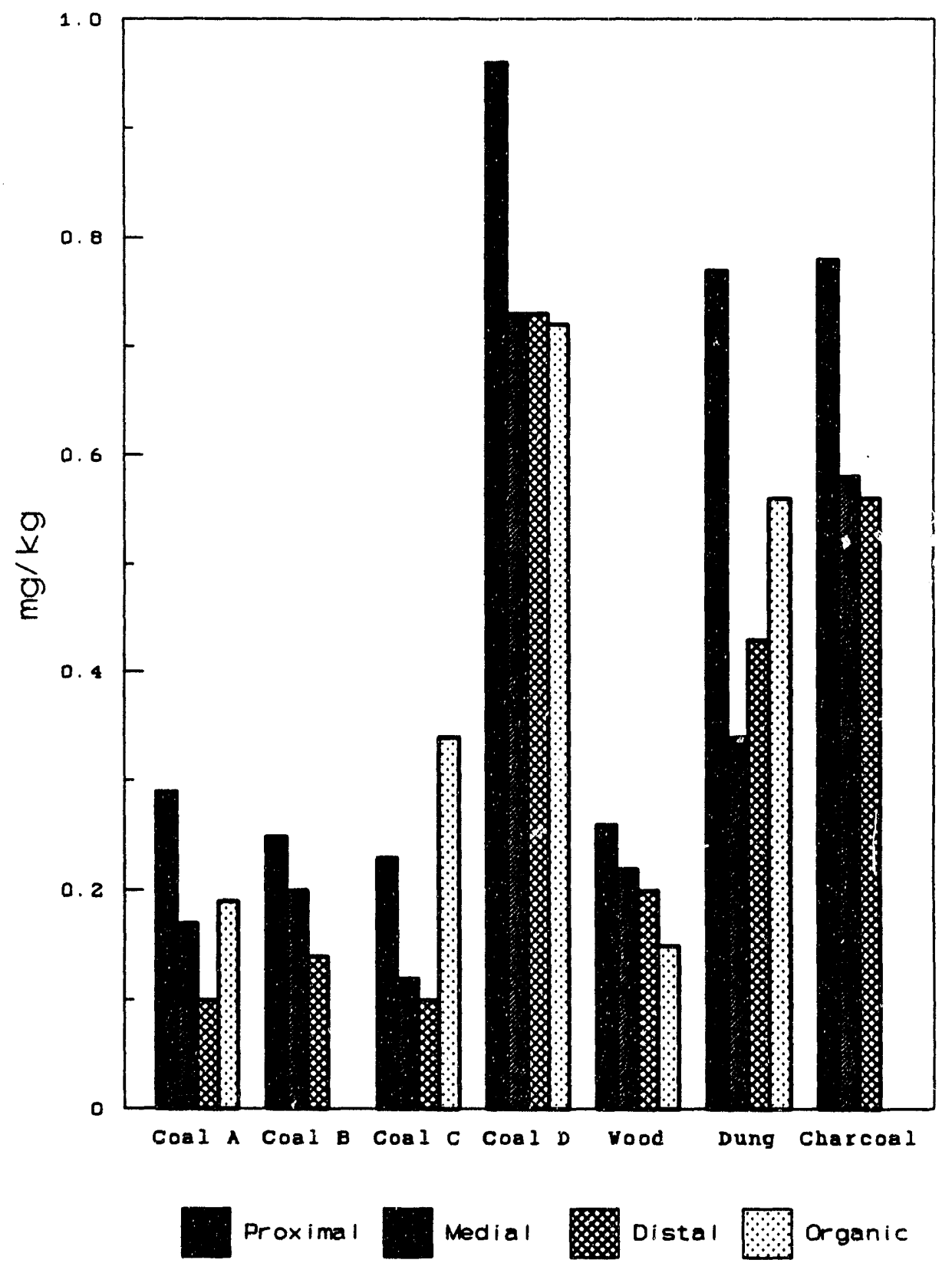

Figure 2. Analysis of inorganic and organic respirable particulates. 


\begin{tabular}{|c|lcr|r|}
\hline \multirow{2}{*}{ Respirable Particulates } & Exposure & Duration & $\mu \mathrm{g} / \mathrm{m}^{3}$ \\
& ALTER & $8 \mathrm{~h}$ & $\leq 40$ \\
\cline { 2 - 4 } & ASTER & $1 \mathrm{~h}$ & $\leq 100$ \\
\hline Total Organics & ALTER & $8 \mathrm{~h}$ & $\leq 5,000$ \\
\hline CO & ALTER & $8 \mathrm{~h}$ & $\leq 11,000$ \\
\cline { 2 - 4 } & ASTER & $1 \mathrm{~h}$ & $\leq 2,500$ \\
\hline \multirow{2}{*}{$\mathrm{SO}_{2}$} & ALTER & $8 \mathrm{~h}$ & $\leq 50$ \\
\cline { 2 - 5 } & ASTER & $5 \mathrm{~min}$ & $\leq 1,000$ \\
\hline \multirow{2}{*}{ NO $_{x}$} & ALTER & $8 \mathrm{~h}$ & $\leq 100$ \\
\cline { 2 - 4 } & ASTER & $5 \mathrm{~min}$ & $\leq 480$ \\
\hline
\end{tabular}

Table 5. Canadian domestic indoor air quality guidelines [2]. ALTER, acceptable long-term exposure range; ASTER, acceptable short-term exposure range.

\begin{tabular}{|c|c|c|c|c|c|c|c|}
\hline & $\begin{array}{c}\text { Std. } \\
\text { Coul }\end{array}$ & Dung & Wood & Codl A & Codl B & Coal C & Coal D \\
\hline $\begin{array}{c}\text { Weight } \\
\text { Collected, } \mu 9\end{array}$ & & $7.0,13.4$ & 3.0 & $10.1,10.4$ & $2.9,3.0$ & 3.4 & $11.3,11.0$ \\
\hline No. Trials & 101 & 2 & 1 & 2 & 2 & 1 & 2 \\
\hline As & 14.0 & n.d. & n.d. & n.d. & n.d. & n.d. & n.d. \\
\hline Be & 1.6 & n.d. & n.d. & n.d. & n.d. & n.d. & n.d. \\
\hline Cd & 2.5 & n.d. & n.d. & n.d. & n.d. & n.d. & n.d. \\
\hline Cr & 13.8 & n.d. & n.d. & n.d. & n.d. & n.d. & n.d. \\
\hline Pb & 34.8 & n.d. & n.d. & n.d. & n.d. & n.d. & n.d. \\
\hline Sb & 13 & n.d. & n.d. & n.d. & n.d. & n.d. & $2.2 \pm 2.9$ \\
\hline So & 2.1 & n.d. & n.d. & n.d. & n.d. & n.d. & n.d. \\
\hline Zn & 272.3 & n.d. & 1.2 & $\begin{array}{c}3.0 \pm \\
\text { n.2B }\end{array}$ & n.d. & 1.2 & $1.8 \pm 0.5$ \\
\hline
\end{tabular}

Table 6. Analyses of inorganic particulates, by ICP/MS, reporting total $\mu \mathrm{g}$ detected. Std. Coal represents the mean concentration (ppm) in 101 coals [3]. n.d., not detected. 
Analyses of the inorganic and organic composition of the collected particulates indicated that no elevated levels of toxic substances were detectable; these data are summarized in Tables 6 and 7. Very low levels of zinc are found in particulates from Coals $A$ and $D$, as well as wood; similarly low levels of antimony are found for Coal D. Fluoranthene is found at levels barely above the detection limit of $100 \mathrm{mg} / \mathrm{Kg}$ of particulates from Coal C. Overall, these levels are quite low, and there is no clear basis for distinction between the briquettes and traditional fuels. Because numerous studies have demonstrated significant levels of polycyclic aromatic hydrocarbons (PAHs) in coal smokes, the organic particulate results are sispicious, and are being repeated.

\begin{tabular}{|c|c|c|}
\hline Sample & Target Compounds & Other Compounds \\
\hline Coal A & n.d. & 10 Hydrocarbons \\
\hline Coal C & $110 \mathrm{mg} / \mathrm{Kg}$ fluoranthene & 12 Hydrocarbons \\
\hline Coal D & n.d. & 12 Hydrocarbons \\
\hline Dung & n.d. & n.d. \\
\hline Wood & n.d. & n.d. \\
\hline
\end{tabular}

Table 7. Analyses of organic particulates, by GCMS. Target compounds, per EPA Method 625. n.d., not detected.

\subsection{ORGANIC VOLATILES}

Organic volatile analyses were conducted during combustion of the fuels; grab samples were collected 15, 30, and 45 minutes into a trial, to estimate flux in emissions from ignition through char-burning phases. Samples were immediately analyzed by photoionization gas chromatography for content of benzene, toluene, and total photoionizable compounds (PIC). Results of these analyses are provided in Table 8, and are shown graphically in Figure 3.

Comparison of GC/PID results shows that, in terms of relative aromatic emissions, rombustion of Coal D generated approximately 4-fold greater concentrations of benzene and toluene than all other fuels. The amended coals and traditional fuels are clustered in a range below about $20 \mathrm{ppm}$. Combustion of the unamended Coal $\mathrm{D}$ briquettes also generated significantly higher levels of total PIC emissions than all other fuels. 


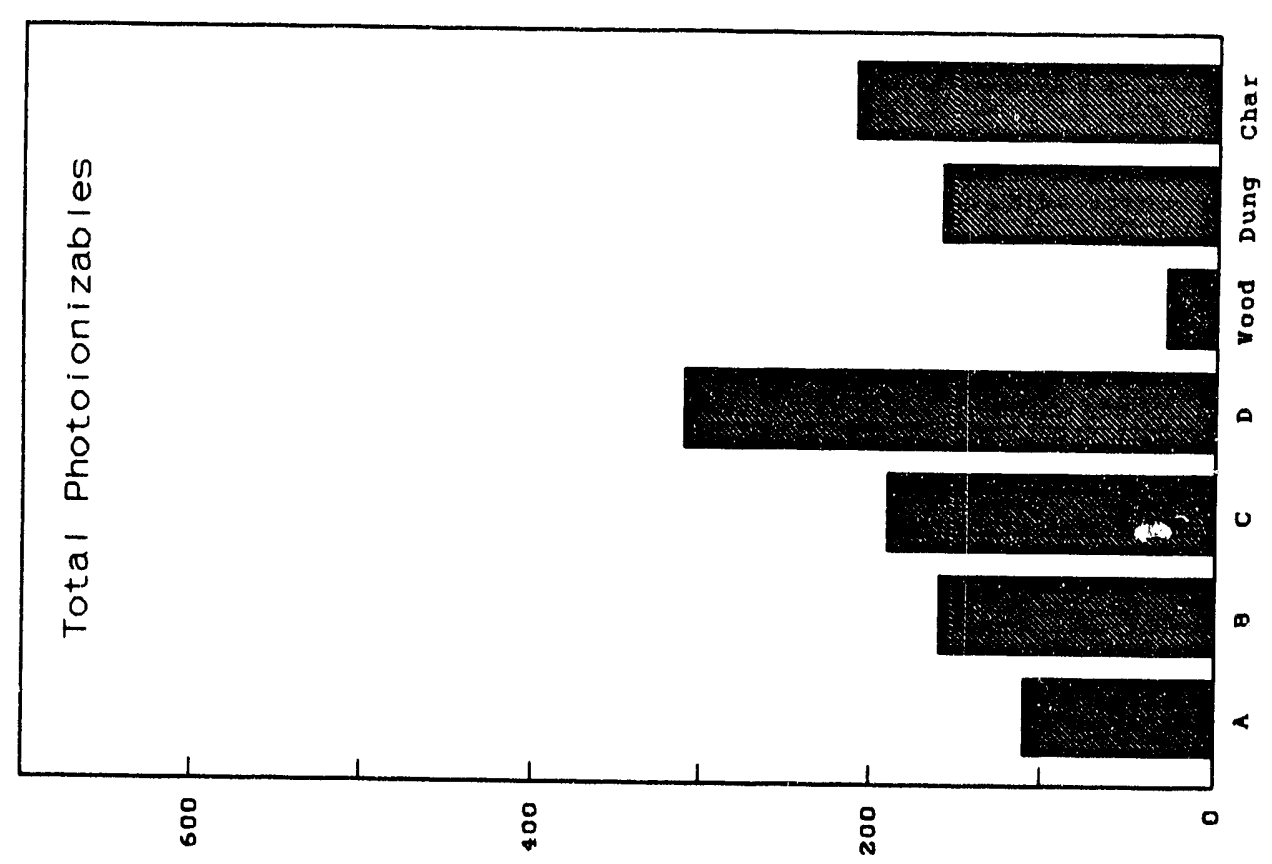

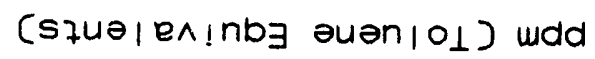

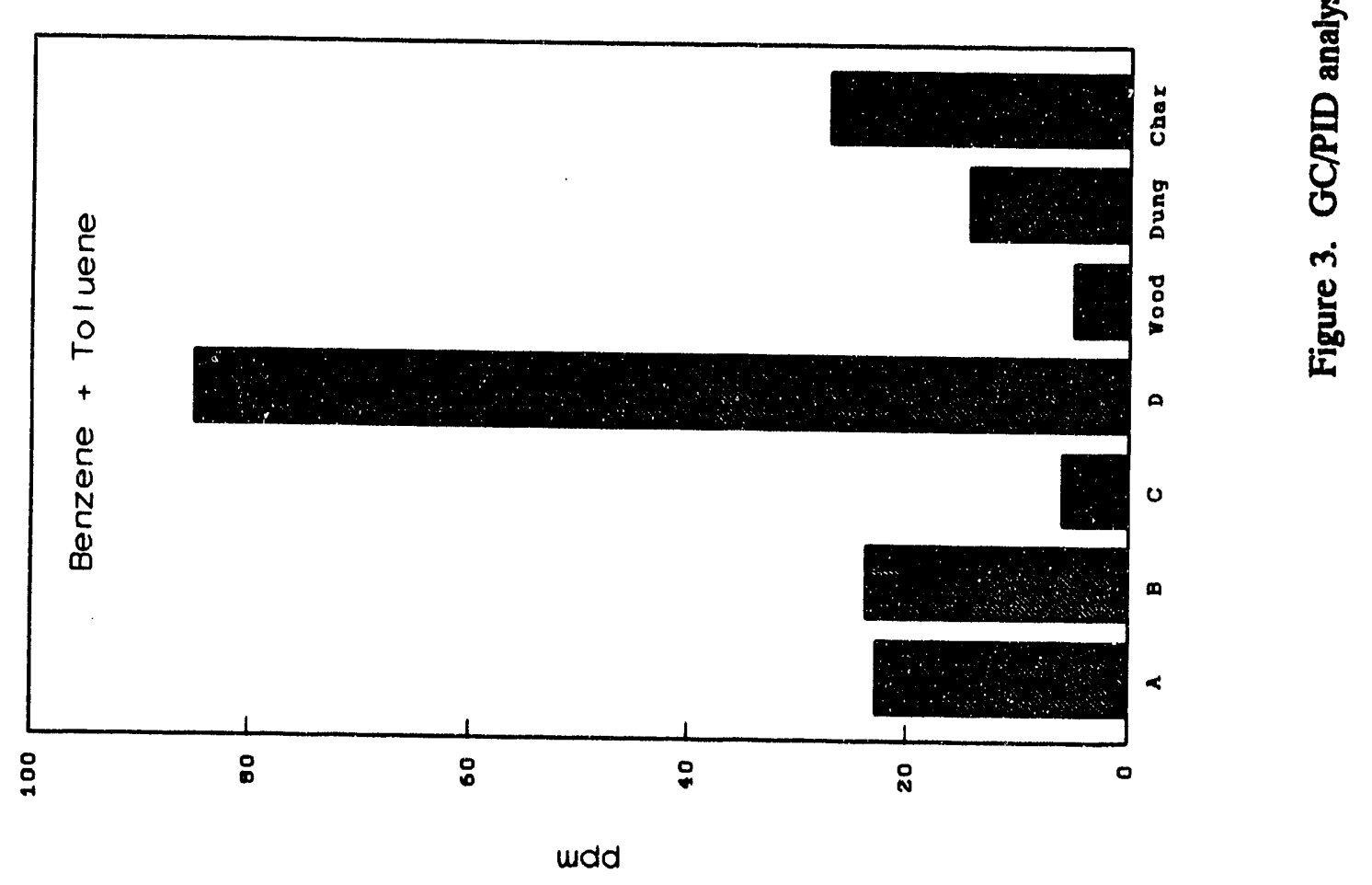




\begin{tabular}{|c|c|c|c|c|c|c|c|c|c|}
\hline \multirow[t]{2}{*}{ Semple } & \multicolumn{3}{|c|}{ Benzeno } & \multicolumn{3}{|c|}{ Toluene } & \multicolumn{3}{|c|}{ Total PIC } \\
\hline & $\begin{array}{c}15 \\
\min \end{array}$ & $\begin{array}{l}30 \\
\text { min }\end{array}$ & $\begin{array}{l}45 \\
\mathrm{~min}\end{array}$ & $\begin{array}{c}15 \\
\min \end{array}$ & $\begin{array}{c}30 \\
\min \end{array}$ & $\begin{array}{l}45 \\
\mathrm{~min}\end{array}$ & $\begin{array}{c}15 \\
\text { min }\end{array}$ & $\begin{array}{c}30 \\
\min \end{array}$ & $\begin{array}{l}45 \\
\mathrm{~min}\end{array}$ \\
\hline Dung & $5.8 \pm 1.8$ & - & 0.6 & $8.5 \pm 0.7$ & - & 0.8 & 160 & - & 13 \\
\hline Wood & 3.7 & 0.5 & n.d. & 1.1 & n.d. & n.d. & 28 & 4 & 4 \\
\hline Charcoel & 11 & 2.0 & n.d. & 16 & 1.1 & n.d. & 210 & 16 & 2 \\
\hline $\operatorname{Coal} A$ & $12.8 \pm 6.2$ & $10.4 \pm 1.6$ & n.d. & $8.9 \pm 7.1$ & $6.0 \pm 4.0$ & n.d. & 110 & 68 & 3 \\
\hline Cond B & 8.6 & 12 & 4.3 & 15 & 16 & 2.0 & 160 & 220 & 34 \\
\hline Coal C & 2.8 & 4.0 & 1.6 & 3.0 & 3.5 & 0.3 & 190 & 180 & 110 \\
\hline Conl D & 52 & 34 & 1.5 & 33 & 15 & 0.4 & 310 & 120 & 4 \\
\hline
\end{tabular}

Table 8. Effluent analysis by photoionization GC. Benzene and toluene in ppm, total PIC in toluene equivalents.

\subsection{ORGANIC VOLATILES AND SEMIVOLATILES}

Integrated VOC and SVOC analyses were conducted on materials entrained on triple sorbent traps during fuel combustion; these samples allow estimatation of total effluent from ignition through char-burning phases. Samples were analyzed by EI-GC/MS, and the resulting fragmentation patterns and relative retention times were used for tentative compound identification. Results are tabulated in Table 9, and shown graphically in Figure 4.

Mirroring the GC/PID results, Coal D produced the highest emissions in nearly all categories, except phenols and furans; no phenols were observed for any of the coals, while these emissions were fairly substantial for the traditional fuels. Emissions of combined benzene, toluene and xylenes (BTX) were considerably greater for Coal D than for any other fuel. In contrast, emissions for the amended coal briquettes were comparable to or lower than those of the traditional fuels for all compound classes. Of interest, emissions of light polycyclic aromatic hydrocarbons (PAHs), having 2- to 3-ring structures, were observed for all fuels; this is contradictory to the organic particulate data, which showed no significant PAH content for any of the fuels. Again, Coal D produced significantly higher levels of this potentially important pollutant category. 

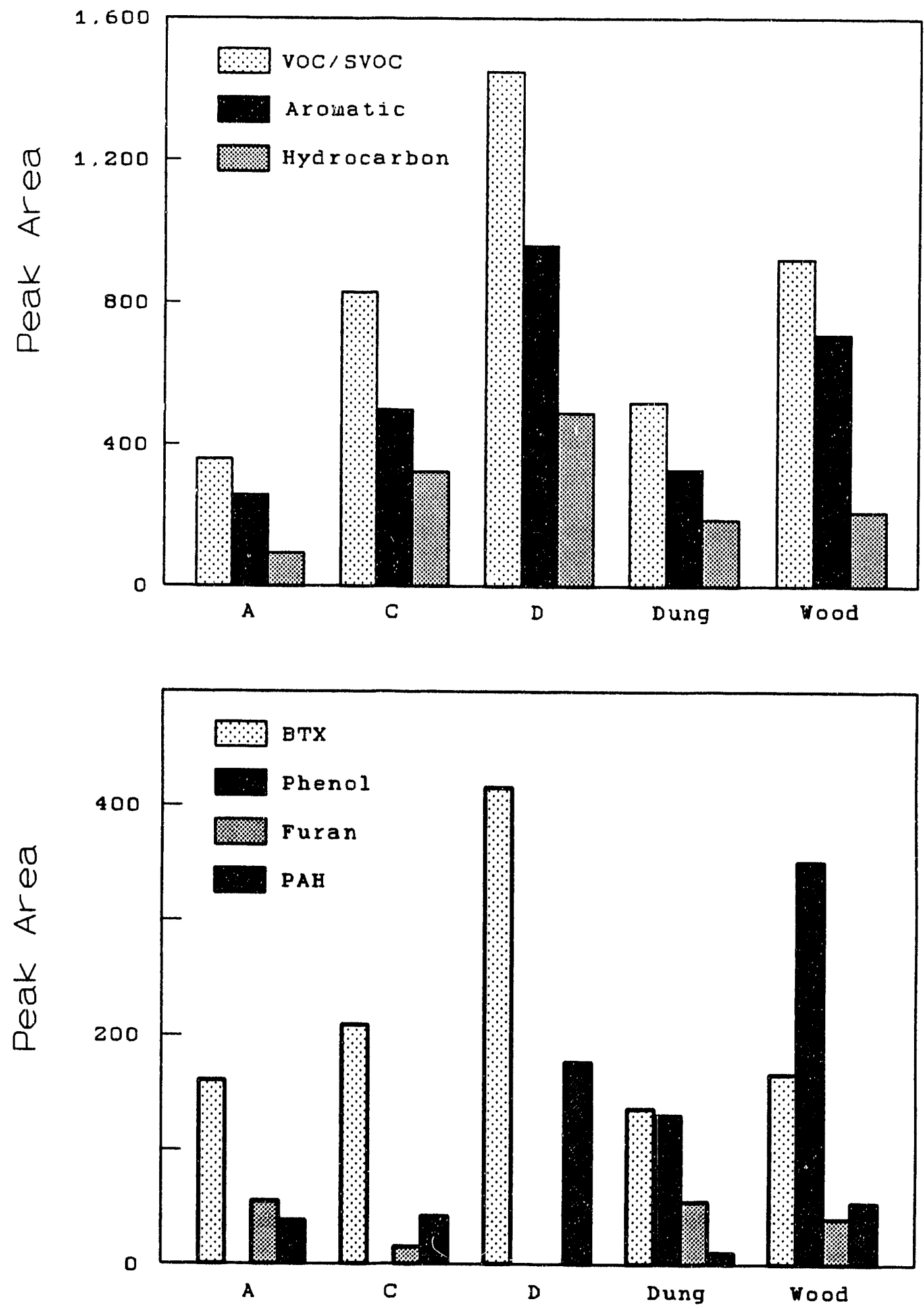

Figure 4. GC/MS analysis of VOC and SVOC combustion products. 


\begin{tabular}{|c|c|c|c|c|c|}
\hline Analyte & Coal A & Coal C & Coal D & Dung & Wood \\
\hline Total Organics & 0.248 & 0.572 & 1.000 & 0.359 & 0.634 \\
\hline Aromatic & 0.179 & 0.345 & 0.662 & 0.228 & 0.490 \\
\hline BTX & 0.110 & 0.143 & 0.286 & 0.094 & 0.114 \\
\hline Phenols & 0.000 & 0.000 & 0.000 & 0.090 & 0.241 \\
\hline Furans & 0.038 & 0.010 & 0.000 & 0.038 & 0.028 \\
\hline PAHs & 0.026 & 0.029 & 0.121 & 0.007 & 0.037 \\
\hline Hydrocarbon & 0.066 & 0.224 & 0.338 & 0.131 & 0.145 \\
\hline
\end{tabular}

Table 9. Relative GC-MS response, by tentative chemical class.

\begin{tabular}{|c|c|c|c|c|c|c|c|c|c|}
\hline & \multicolumn{3}{|c|}{ co } & \multicolumn{3}{|c|}{$\mathrm{NO}_{x}$} & \multicolumn{3}{|c|}{$\mathrm{SO}_{2}$} \\
\hline & [PK] & $t$ & EF & [Pk] & $t$ & EF & [Pk] & $t$ & EF \\
\hline Coal A & 92 & 0.30 & 26 & 2.2 & 0.18 & 0.32 & 14.6 & 0.32 & 2.2 \\
\hline Coal B & 277 & 0.22 & 42 & 6.2 & 0.17 & 0.58 & 15.1 & 0.20 & 1.7 \\
\hline Coal C & 138 & 1.18 & 50 & 0.7 & 0.28 & 0.19 & 13.8 & 0.25 & 3.5 \\
\hline Coal D & 179 & 0.33 & 54 & 1.8 & 0.27 & 0.34 & 18.2 & 1.18 & 7.2 \\
\hline Wood & 239 & 0.20 & 34 & 1.9 & 0.22 & 0.31 & 11.2 & 0.33 & 2.0 \\
\hline Dung & 203 & 0.53 & 41 & 8.4 & 0.15 & 0.57 & 15.4 & 0.32 & 2.5 \\
\hline Shar & 313 & 0.57 & 66 & 2.5 & 0.60 & 0.63 & 6.8 & 0.57 & 1.4 \\
\hline
\end{tabular}

Table 10. Peak concentrations ([Pk] in $\left.\mathrm{mg} / \mathrm{m}^{3}\right)$, peak times ( $\mathrm{t}$ in hours), and relative emission factors ( $\mathrm{EF}$ in $\mathrm{g} / \mathrm{kg}$ ) for inorganic oxides.

\subsection{CARBON MONOXIDE}

Results from continuous monitoring of carbon monoxide levels throughout combustion are provided in Table 10, and are shown graphically in Figure 5. While no major differences are noted between fuels, several general observations are possible. Obviously the briquettes are comparable or lower than the traditional fuels in peak and total $\mathrm{CO}$ emissions; however, 

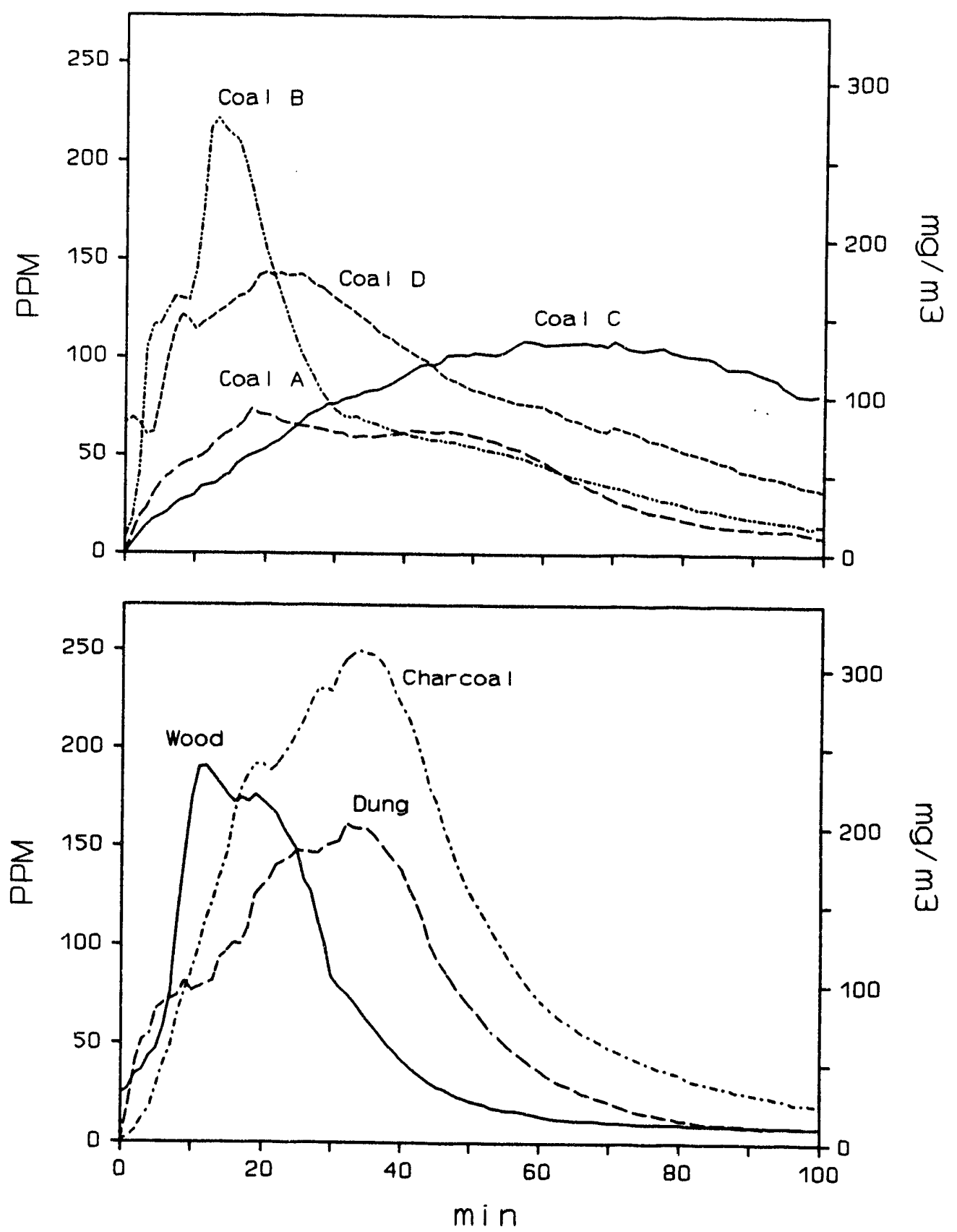

Figure 5. Carbon monoxide emissions. 
since peak concentrations significantly exceed the $25 \mathrm{mg} / \mathrm{m}^{3}$ ASTER level [2] and may produce transient or long-term toxic effects, the $\mathrm{CO}$ emissions of all fuels tested are significant. Emissions are generally greatest immediately following ignition, and tend to decrease rapidly upon transition to the char-phase of burning. $\mathrm{CO}$ emissions for the briquettes are proportional to the fraction of combustible fuel present (inversely proportional to weight percentage of additives), suggesting that the fuel additives have no significant effect on CO emission per unit of matter burned.

\subsection{NITROGEN OXIDES}

Results from continuous monitoring of nitrogen oxide levels are provided in Table 10, and shown in Figure 6. No clear trends are obvious from this data; note however, that $\mathrm{NO}_{\mathrm{x}}$ levels are relatively high for all fuels (ASTER NO ${ }_{x} 480 \mu \mathrm{g} / \mathrm{m}^{3}$ ). No significant background was detected for the propane torch used as an ignition source. Hence, differences in measured $\mathrm{NO}_{\mathrm{z}}$ levels seem to be primarily related to characteristics of the fuels.

\subsection{SULFUR DIOXIDE}

Results from continuous monitoring of sulfur dioxide levels are provided in Table 10, and shown in Figure 7. Charcoal is significant for its low peak and total $\mathrm{SO}_{2}$ emissions, while Coal $D$ is equally significant for its elevated total emissions; the amended coals and the other traditional fuels are comparable in terms of peak and total emissions. Amendment has the benefit of reducing total $\mathrm{SO}_{2}$ emissions from the low-range coals, but peak emissions for all fuels are still significant (ASTER $\left.\mathrm{SO}_{2}, 1 \mathrm{mg} / \mathrm{m}^{3}\right)$.

\subsection{COMPARISON OF OXIDE RESULTS}

Oxide emission profiles are compared in Figure 8; this figure allows relative comparison of peak and integrated emission factors for all fuels. it is clear from this representation that emissions from the coal briquettes are comparable to or lower than those from the traditional fuels, with the significant exception of $\mathrm{SO}_{2}$ emissions from the unamended Lakhra coal briquettes (Coal D). 

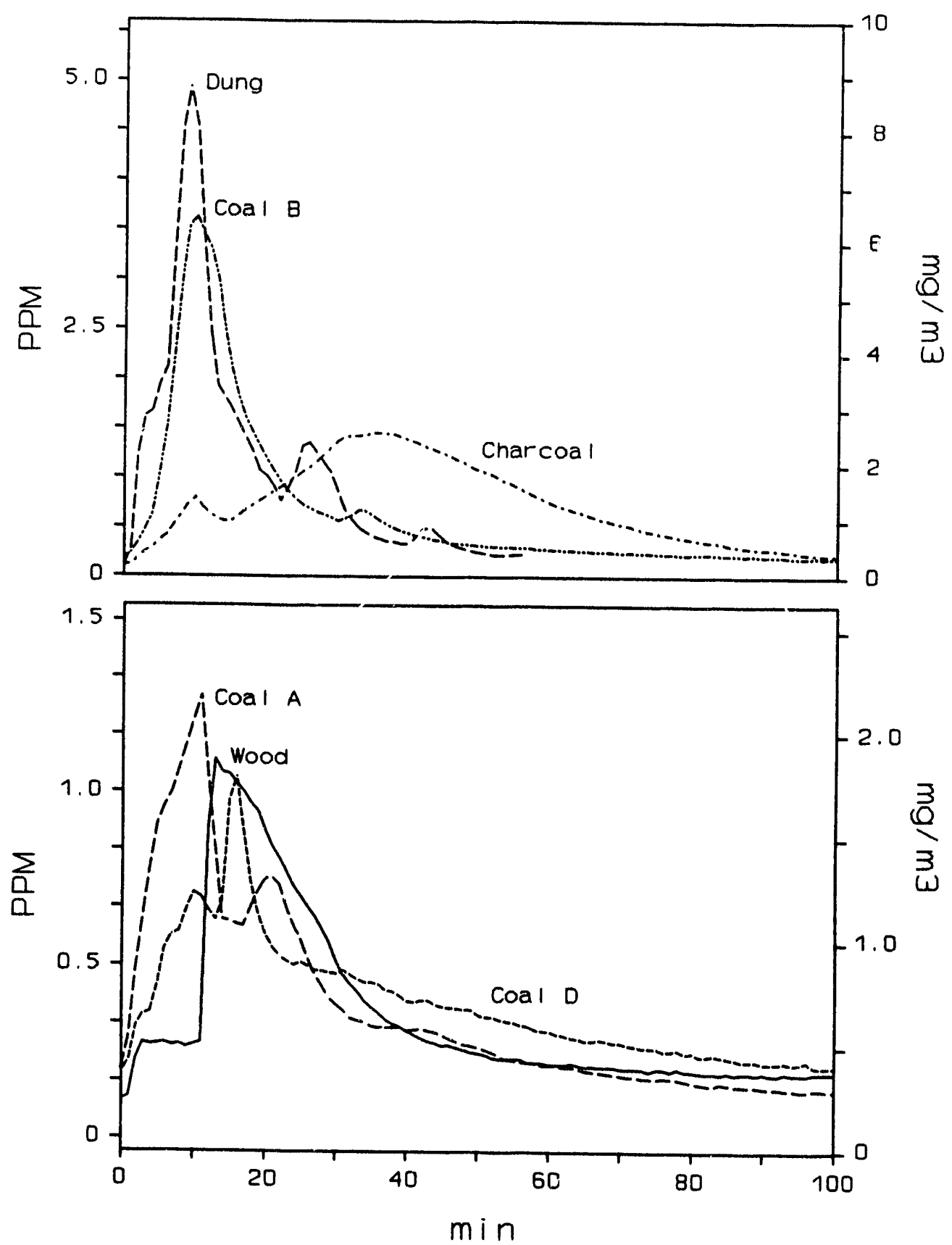

Figure 6. Nitrogen oxides emissions. 

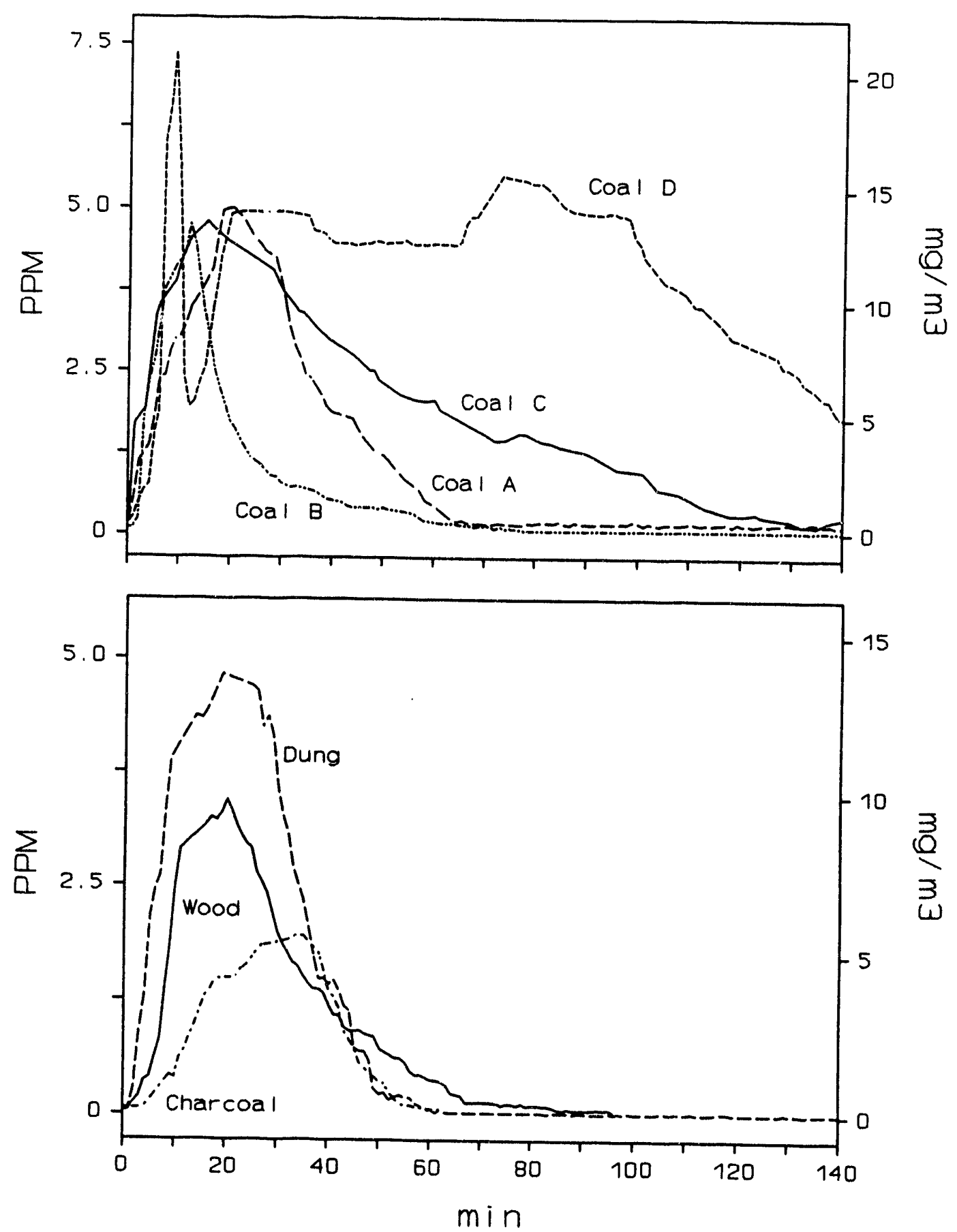

Figure 7. Sulfur dioxide emissions. 

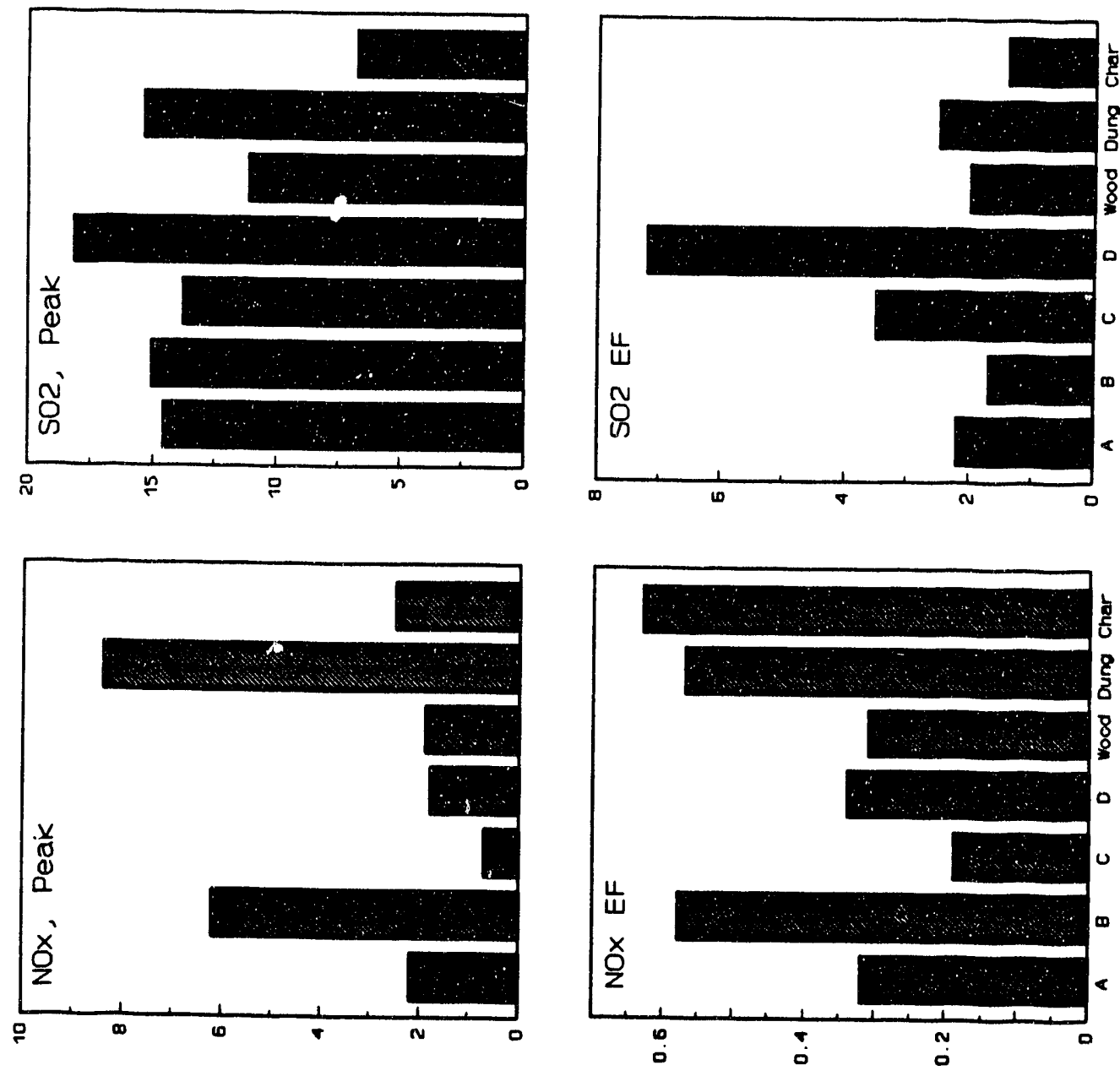

물.

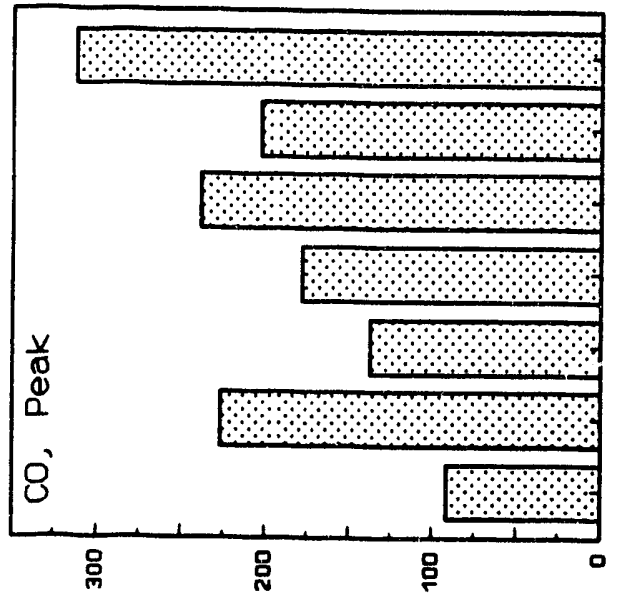

Ew/ 6w

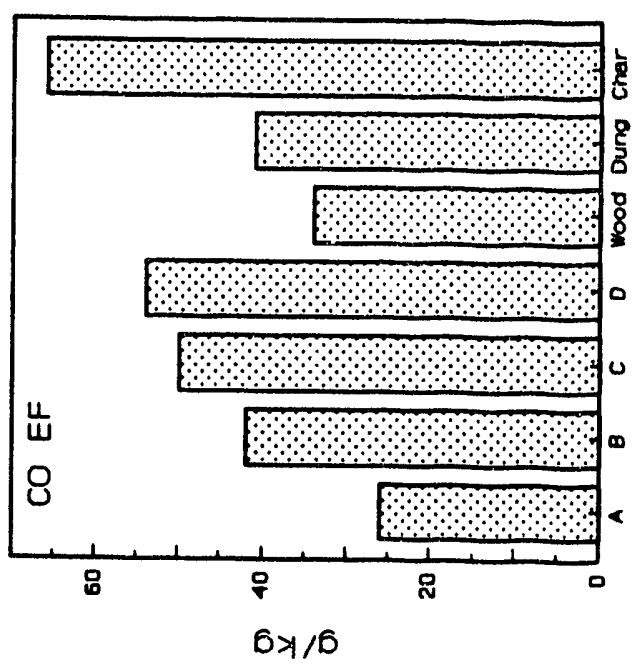




\section{SUMMARY}

The purpose of the coal briquette study was to measure and evaluate combustion emissions from Pakistani domestic fuels. Under normal fuel usage conditions, where fuels are burned indoors in unvented, open stoves, pollutant emissions may be at levels sufficient to pose both acute and chronic health threats. The results permit comparison on a relative scale between emissions from amended coal briquettes, unamended coal briquettes, and traditional fuels such as wood, wood charcoal, and animal dung. Overall, it appears that emissions from the amended coal briquette products are comparable to or lower than those from traditional fuels for all pollutant categories investigated (organic and inorganic respirable particulates, VOC and $\mathrm{SVOC}$ emissions, and $\mathrm{CO}, \mathrm{NO}_{x}$ and $\mathrm{SO}_{2}$ emissions). Emissions of particulates, VOCs and SVOCs, and of total sulfur dioxide appear to be significantly reduced for loiv-range coal briquettes via the introduction of the amendments shown in Table 1.

These generally favorable pronouncements need further qualification. The peak emissions and relative emission factors are valid only for the standard conditions used in our tests (i.e., $200 \mathrm{~g}$ charge of fuel burned in a medium-sized Angethi stove inside a $12 \mathrm{~m}^{3}$ shed at an air exchange rate of $14 \mathrm{~h}^{-1}$ ). This relatively small charge of fuel was needed to accommodate the high sensitivities of our monitoring devices. Such a small charge of fuel resulted in rather uneven and sometimes incomplete burning. Coal briquettes were frequently left with an unburned core which complicated calculation of emission factors. Further tests should be conducted under more representative conditions of fuel loading (ca. 1-1.5 kg) of the Angethi stoves; provision for dilution of the sampled air will probably be necessary to protect monitoring equipment.

Potential heath affects resulting from high peak exposures soon after initial firing can be avoided by lighting the stove in the open and later moving the burning stove inside. If combustion is conducted in this manner, the coal briquettes with additives become even more attractive as an alternative for traditional domestic fuels from a human health perspective. 


\section{REFERENCES}

1. D. L. Wilson and A. R. Hawthorne. Comparison of Combustion Pollutants from Charania Briquettes, Consumer Barbeque Briquettes, Pakistani Mineral Development Corporation Briquettes, and Pakistani Wood Charcoal, ORNL/TM-10557, Martin Marietta Energy Systems, Inc., Oak Ridge National Laboratory, 1987.

2. Canadian Domestic Indoor Air Quality Guidelines, Federal Provincial Advisory Committee on Environmental and Occupational Health, Environmental Health Directorate, Health Protection Branch, April 1987.

3. R. R. Ruch, H. J. Gluskoter, and N. F. Shrimp, "Occurrence and Distribution of Potentially Volatile Trace Elements in Coal: A Final Report," Environ. Geol. Notes 72. Illinois State Geological Survey (1974). 
ORNL/TM-12087

Dist. Category 407

\section{INTERNAL DISTRIBUTION}

1. B. A. Berven

2-3. J. C. DePriest

4. K. F. Eckerman

5. W. Fulkerson

6. E. L. Fulier

7-11. R. B. Gammage

12-13. J. W. Haas

14. R. N. Hamm

15. C. E. Higgins

16. S. V. Kaye

17. C. A. Little

18. P. Y. Lu

$19 . \quad$ C. Y. Ma

$20 . \quad$ J. C. Miller

$21 . \quad$ P. S. Rohwer

22. D. E Reichle

$23 . \quad$ R. B. Shelton

24. R. E. Swaja

25. T. Vo-Dinh

26-30. E. A. Wachter

31-32. J. Wade

33. A. Watson

34-35. D. L Wilson

$36 . \quad$ T. J. Wilbants

37-j8. Central Research Library

39. Document Reference Section

40-41. Laboratory Records Department

42. Laboratory Records Department - RC

43. ORNL Patent Office

\section{EXTERNAL DISTRIBUTION}

44-45. N. Ahmad, Director, Fuel Research Center, PSCIR off University Road, Karachi-39, Pakistan

46. R. Archer, 320 21st Street, NW, Room 4440, Washington, DC 20523-0053

47-48. C. Duisberg, Deputy Chief, O/PEN, U.S. Agency for International Development, Islamabad, Pakistan

49. Y. Liu, East-West Environment and Policy Institute, East-West Center, 1777 East-West Road, Honolulu, HI 96848 
50. P. O'Neill, John Graymore Chemistry Laboratories, Department of Environmental Sciences, Polytechnic South West, Plymouth, PLA8AA, Devon, United Kingdom

51-52. M. Zahid Raza, Fuel Research Center, PSCIR off University Road, Karachi39, Pakistan

53-54. F. Sibtain, Fuel Research Center, PSCIR off University Road, Karachi-39, Pakistan

55. K. Smith, East-West Environment and Policy Institute, East-West Center, 1777 East-West Road, Honolulu, HI 96848

56. G. Stevenson, 331 Bryant Avenue, Apt. 2, Cincinnati, OH 45220

57. J. Swift, Energy Advisor, Office of Energy, Mission of Pakistan, U. S. Agency forInternational Development, Islamabad, Pakistan

58. Office of Assistant Manager for Energy Research and Development, Department of Energy, Oak Ridge Operations, Oak Ridge, Tennessee 37831

59-68. Office of Scientific and Technical Information, P. O. Box 62, Oak Ridge, TN 37831 

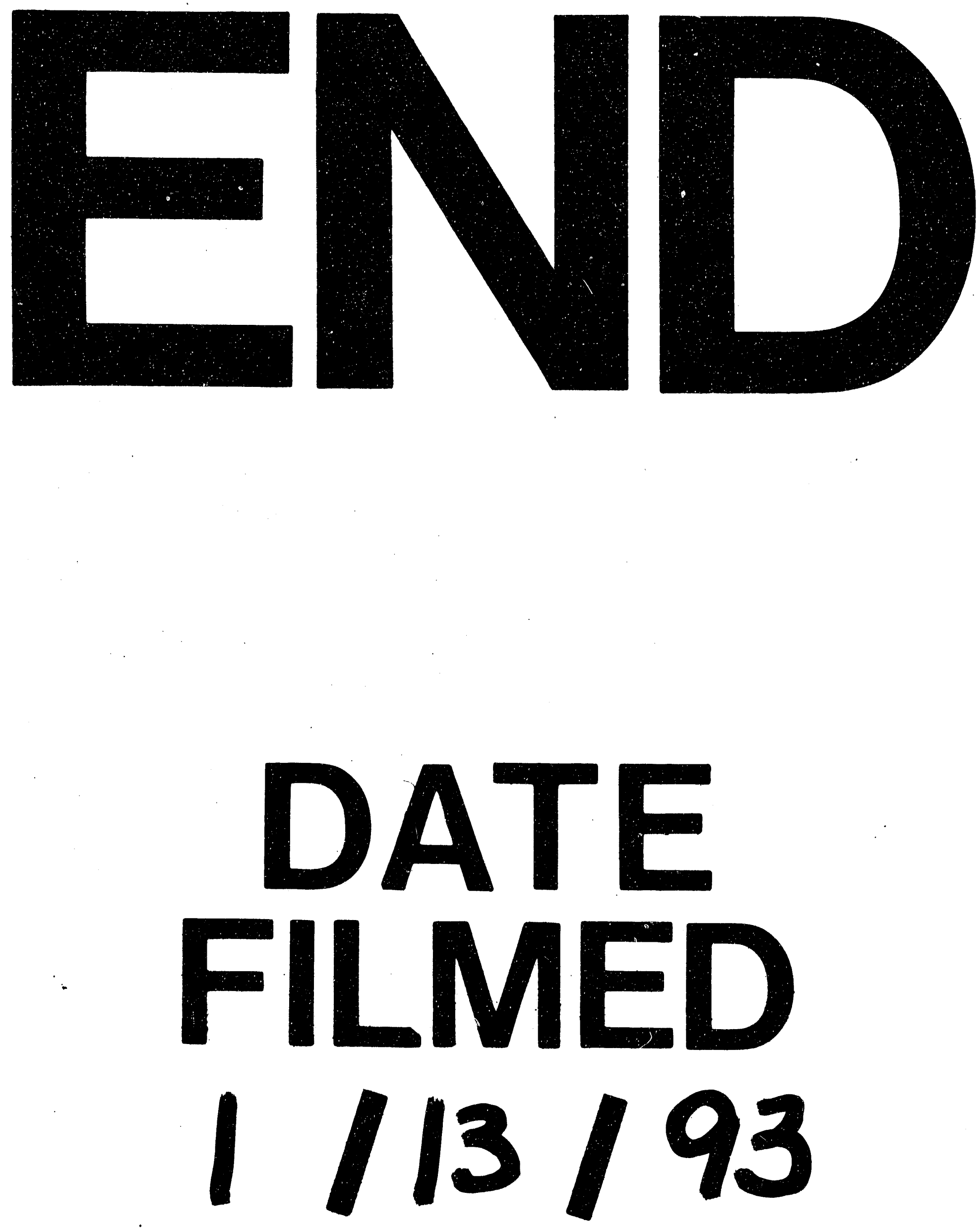
